\title{
Burden of Informal Caregivers of Chronic Respiratory Failure Patients in Croatia
}

\author{
Snježana Benko',2, Branko Kolarićc ${ }^{3,4}$, Nada Tomasović Mrčela ${ }^{1,3,5}$ \\ ${ }^{1}$ Alma Mater Europaea - ECM, Slovenia \\ ${ }^{2}$ Special Hospital for Lung Disease, Zagreb, Croatia \\ ${ }^{3}$ Andrija Štampar Teaching Institute of Public Health, Zagreb, Croatia \\ ${ }^{4}$ Faculty of Medicine, University of Rijeka, Rijeka, Croatia \\ ${ }_{5}^{5}$ University Department of Health Studies, University of Split, Split, Croatia
}

\begin{abstract}
A B S T R A C T
The aim of this study was to determine the level of burden of informal caregivers of chronic respiratory failure patients measured by the Zarit Burden Interview Questionnaire (ZBI) and to identify overburdened informal caregivers who can become hidden patients. We recruited the respondents in two hospitals for lung disease and a home healthcare service in Zagreb during 2020. After they had been identified as primary informal caregivers who provided high intensity informal care for more than six months, they were asked to complete the Croatian version of the ZBI questionnaire and a questionnaire on sociodemographic characteristics. We used descriptive methods for statistical analysis in this cross-sectional study. We presented the data in tables as absolute frequencies, percentages and measures of the central tendency, and graphically by using diagrams. The study included 150 informal caregivers. The majority were female, over 50 years of age with high school education. The largest percentage of informal caregivers was retired. The highest scores were given to the statements on worrying about future and patient dependency while the lowest scores were given to the statements on leaving the care to someone else and feelings such as anger or embarrassment caused by the patient. The results of this study show that more than half of informal caregivers of chronic respiratory failure patients are moderately to severely burdened.
\end{abstract}

Key words: burden, informal caregiving, chronic respiratory failure

\section{Introduction}

The aging population and the increased prevalence of chronic diseases are the main reasons for the necessity of long-term care ${ }^{1}$. There are two models of long-term care. Formal long-term care is performed in health and social institutions by health professionals while informal long-term care is performed in the patient's home mostly by a member of the family who is called informal caregiver ${ }^{2,3}$. Informal caregiving includes two main types of interventions: interventions for assisting in daily activities which includes personal care, and medical interventions such as managing medications, helping with assistive devices (canes and walkers) for mobility, preparing food for special diets, wound care, using meters or monitors, including glucometers to test blood sugar levels, managing incontinence equipment, operating durable medical equipment, such as lifts to get people out of bed, operating medical equipment, including mechanical ven- tilators, tube feeding equipment, home dialysis, and suctioning ${ }^{4,5}$. Providing informal care may be high intensity care including more than 20 hours per week of informal caregiver's helping or low intensity care including less than 20 hours per week of help ${ }^{6}$. The final decision on choosing between formal or informal care is based on the traditional and social values, economic, and demographic factors. The elderly mostly prefer staying with their families ${ }^{7}$. Informal caregivers usually do not have enough time to take care of their own health. Providing care during a prolonged period can be very stressful and present a burden. Feeling unprepared for providing care, lack of support from the society and insufficient coping skills for everyday challenges of care are among the most important predictors of informal caregiver's burden. Overburdened informal caregivers are hidden patients ${ }^{8-10}$. The concept of informal caregiver's burden appeared in scientific literature 60 years ago and it is related to the feeling of overburden, loss of control over life, social iso-

Received for publication September 18, 2020 
lation, and bad communication as result of providing care. Burden of informal caregivers is an acute reaction to care demands and reflects informal caregiver's subjective perception of stressors ${ }^{11-12}$. The negative impacts of informal caregiving on caregiver's life that may occur are increased stress, mental health problems, cardiovascular disease, other chronic conditions, and changes in immunity, changes in family relations and in emotional and intimate life $\mathrm{e}^{13-17}$.

The purpose of this study was to determine the level of burden of informal caregivers of chronic respiratory failure patients measured by a commonly used tool - the Zarit Burden Interview Questionnaire and to identify overburdened informal caregivers who can become hidden patients. The sociodemographic characteristics of informal caregivers were also collected and presented. According to available research findings and publications, this study investigates the burden of informal caregivers of chronic respiratory failure patients in Croatia for the first time.

\section{Materials and Methods}

\section{Study design}

This descriptive, cross-sectional study was designed to measure the burden level of informal caregivers of chronic respiratory failure patients in Croatia using an official Croatian version of the Zarit Burden Interview Questionnaire. The study included informal caregivers of chronic respiratory failure patients who came to two specialized hospitals for lung diseases for a regular medical check-up or were users of formal nursing care. This study was conducted in full accordance with the ethical guidelines of the Declaration of Helsinki and approved by the relevant ethics board.

\section{Informal caregivers' data collection and measurement}

Informal caregivers' data was collected in two ways. The first one was during the regular monitoring of the patients' underlying disease which caused the chronic respiratory failure. The principal investigator was informed if a patient came with a person who could be identified as potential informal caregiver. When the investigator determined that the accompanying person could be defined as the primary informal caregiver and that they met the conditions of the inclusion criteria, they were asked to join the trial. The second way was by contacting a home healthcare service in Zagreb and asking for the information on their users who suffered from chronic respiratory failure and used some type of respiratory support. The investigator contacted their family members and by asking a set of questions identified primary informal caregiver. The participants were recruited in the period from January 2020 until November 2020 when required number of 150 respondents was obtained. According to available data from the Croatian Institute of Public Health, there are 234 persons in the City of Zagreb who suffer from respiratory insufficiency. Since not all of these patients require informal care, the 150 primary informal caregivers of the aforementioned group of patients make up $65 \%$ of the target population, which can be considered a representative sample. All participants were selected by using the following inclusion criteria: over 18 years of age, taking care of chronic respiratory failure patients for more than 6 months, patients using some type of respiratory support (oxygen therapy, noninvasive or invasive mechanical ventilation), providing high intensity care (more than 20 hours per week), and living with the patient in the same household. All participants were informed of the purpose of the study and participation in the study was voluntary. The participants signed the Consent form, filled in a questionnaire with sociodemographic information, and completed the official Croatian version of the Zarit Burden Interview Questionnaire.

\section{Zarit Burden Interview Questionnaire (ZBI)}

The official Croatian version of the ZBI was used in this study. Permission was requested from and given by the Mapi Research Trust Organization (Copyright 1980, 1983, 1990 Steven H Zarit and Judy M Zarit). Originally, the ZBI was available only in English but it was later translated and adapted to several languages. The ZBI is one of the most commonly used instruments for measuring the burden level of informal caregivers taking care of patients with various diseases ${ }^{18-21}$. The questionnaire consists of 22 items covering the caregiver's health, psychological wellbeing, social life and finances. The answers are rated on a 5-point Likert scale that ranges from 0 (never) to 4 (nearly always) with the sum of scores ranging between 0 and $88^{22}$. Higher scores indicate greater perceived caregiver's burden. Scores ranging from 61 to 88 identify severe burden, 41 to 60 moderate to severe burden, 22 to 40 mild to moderate burden and less than 21 little or no burden. The ZBI was developed as a unidimensional measure of burden ${ }^{23,24}$ but later studies on informal caregivers have reported other dimensions such as patient's dependence, exhaustion and uncertainty, guilt or self-criticism, embarrassment/anger or frustration, psychological burden and emotional reactions, personal strain, and role strain ${ }^{25-29}$. According to the Mapi Research Trust Concept of Mapping there are five domains: burden in relationships, emotional well-being, social and family life, finances, and loss of control over one's life (Mapi Research Trust Organization).

\section{Statistics}

We performed a cross-sectional study and used descriptive methods for statistical analysis. As part of the descriptive analysis, the data are presented in tables as absolute frequencies, percentages and measures of the central tendency, and graphically as diagrams. Data are presented by arithmetic mean, standard deviation, minimum and maximum values. The threshold for statistical significance was set at $p<0.05$. All calculations were performed using the statistical analysis software package SPSS (26.0, SPSS Inc., Chicago, IL, SAD). 


\section{Results}

The study included 150 informal caregivers of chronic respiratory failure patients. Participants were enrolled from two hospitals for lung diseases in Zagreb $(\mathrm{N}=132)$ and by telephoning families whose chronic respiratory failure patient/family member was registered in a Home health care service in Zagreb $(\mathrm{N}=28)$. The study was conducted in the period from January to November 2020. The majority of patients used long-term oxygen therapy $(\mathrm{N}=101)$, further non-invasive mechanical ventilation and oxygen therapy $(\mathrm{N}=25)$ and invasive mechanical ventilation $(\mathrm{N}=24)$ as respiratory supports. Sociodemographic characteristics of participants are presented in Table 1.

The questionnaire analysis showed that the highest scores were given to the statements on worrying about the future and patient dependency, while the lowest scores were given to the statements on leaving the care to someone else and feelings such as anger or embarrassment caused by the patient (Table 2). After scoring all ZBI questionnaires, the participants were divided in categories according to burden (Figure 1).
TABLE 1

SOCIODEMOGRAPHIC CHARACTERISTICS OF PARTICIPANTS

\begin{tabular}{llrr}
\hline Variable & & $\mathrm{N}$ & \multicolumn{1}{c}{$\%$} \\
\hline Gender & \multicolumn{1}{c}{$\mathrm{M}$} & 19 & 12.67 \\
& Total & 131 & 87.33 \\
Age & $0-49$ & 150 & 10.00 \\
& 50 and over & 40 & 26.67 \\
Level of education & Total & 110 & 73.33 \\
& Primary education & 150 & 100.00 \\
& High school & 16 & 10.67 \\
& Bachelor's degree & 14 & 66.67 \\
Work status & Master's degree & 20 & 9.33 \\
& Total & 150 & 100.33 \\
& Full time job & 49 & 32.67 \\
& Part time job & 5 & 3.33 \\
& Parent caregiver & 9 & 6.00 \\
& Retirement & 62 & 41.33 \\
& Student & 1 & 0.67 \\
& Unemployed & 24 & 16.00 \\
& Total & 150 & 100.00 \\
\hline
\end{tabular}

TABLE 2

ANALYSIS OF THE ZBI QUESTIONNAIRE

\begin{tabular}{|c|c|c|c|c|}
\hline Question & $\overline{\mathrm{x}}$ & $\mathrm{Sd}$ & Min & Max \\
\hline Do you feel that your relative asks for more help than he/she needs? & 2.01 & .94 & .00 & 4.00 \\
\hline $\begin{array}{l}\text { Do you feel that because of the time you spend with your relative you don't have enough time } \\
\text { for yourself? }\end{array}$ & 2.38 & .85 & .00 & 4.00 \\
\hline $\begin{array}{l}\text { Do you feel stressed between caring for your relative and trying to meet other responsibilities } \\
\text { for your family or work? }\end{array}$ & 2.56 & .92 & .00 & 4.00 \\
\hline Do you feel embarassed over your relative's behavior? & 1.41 & 1.05 & .00 & 3.00 \\
\hline Do you feel angry when you are around your relative? & 1.42 & 1.01 & .00 & 3.00 \\
\hline $\begin{array}{l}\text { Do you feel that your relative currently affects your relationship with other family members or } \\
\text { friends in a negative way? }\end{array}$ & 1.64 & 1.11 & .00 & 3.00 \\
\hline Are you affraid what the future holds for your relative? & 3.13 & .78 & .00 & 4.00 \\
\hline Do you feel your relative is dependent upon you? & 3.11 & .84 & 1.00 & 4.00 \\
\hline Do you feel strained when you are around your relative? & 1.79 & .94 & .00 & 4.00 \\
\hline Do you feel your health has suffered because of your involvement with your relative? & 1.89 & .85 & .00 & 4.00 \\
\hline Do you feel that you don't have as much privacy as you would like, because of your relative? & 2.35 & .94 & .00 & 4.00 \\
\hline Do you feel that your social life has suffered because you are caring for your relative? & 2.42 & .89 & .00 & 4.00 \\
\hline Do you feel uncomfortable about having friends over, because of your relative? & 1.50 & 1.18 & .00 & 4.00 \\
\hline $\begin{array}{l}\text { Do you feel that your relative seems to expect you to take care of him/her, as if you were the } \\
\text { only one he/she could depend on? }\end{array}$ & 2.62 & .96 & .00 & 5.00 \\
\hline $\begin{array}{l}\text { Do you feel that you don't have enough money to care for your relative, in addition to the rest } \\
\text { of your expenses? }\end{array}$ & 2.31 & 1.13 & .00 & 4.00 \\
\hline Do you feel that you will be unable to take care of your relative much longer? & 1.85 & .98 & .00 & 4.00 \\
\hline Do you feel you have lost control of your life since your relative's illness? & 1.92 & 1.03 & .00 & 4.00 \\
\hline Do you wish you could just leave the care of your relative to someone else? & 1.25 & .85 & .00 & 4.00 \\
\hline Do you feel uncertain about what to do about your relative? & 1.50 & .94 & .00 & 4.00 \\
\hline Do you feel you should be doing more for your relative? & 2.13 & 1.02 & .00 & 4.00 \\
\hline Do you feel you could do a better job in caring for your relative? & 2.04 & 1.01 & .00 & 4.00 \\
\hline Overall, how burdened do you feel in caring for your relative? & 2.48 & .82 & .00 & 4.00 \\
\hline
\end{tabular}




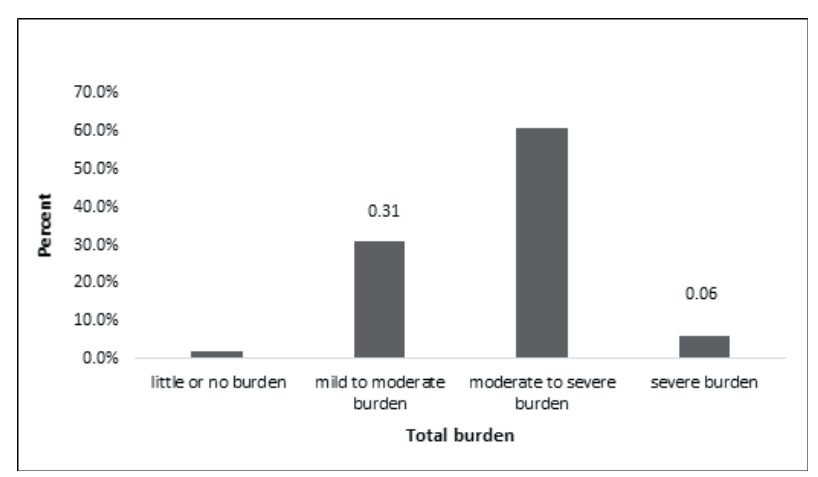

Fig. 1. Burden categories among participants.

\section{Discussion}

The necessity for informal long-term care is proportional with the increased number of the elderly and the chronically ill patients. As it is well known, caring for an ill member of the family can lead to a negative impact on the informal caregivers' physical and mental health and social life $\mathrm{e}^{6,8,30-32}$. Caring for someone who is critically ill and on some type of respiratory support may result in a significant burden of care providers ${ }^{33,34}$. The burden is proportional with the disease progression and worsening of symptoms, especially if the hospitalization is required ${ }^{35}$. Care provider's burden level is one of the major indicators for determining the quality and outcomes of care and has one of the main roles in making the final decision about the institutionalization of an ill member of the family ${ }^{36,37}$. As overburden is one of the main predictors for a negative impact on the informal caregiver, it is very important to identify the overburdened informal caregivers by using a valid and reliable tool ${ }^{38-42}$. This study results showed that informal caregivers of chronic respiratory failure patients in Croatia are moderately to severely burdened. The mean age of care providers is 57, they are mostly female (wives and daughters) and only one third of them worked full time which correlates with the results of other studies $^{6,33,43-45}$. These findings suggest that informal caregivers in Croatia may be in high risk for development of physical and mental disorders, especially because of their mean age. One of the major problems in the implementation of informal care could be the increasing work engagement of women. Support services have to be organized to help achieve the balance between women's work life and family responsibilities, and providing informal care ${ }^{46}$.

The questionnaire analysis showed that the informal caregivers were very worried about the patient's future but they rarely thought about leaving care to someone else. Although they were burdened, they usually did not feel angry nor had negative feelings. As there are numerous benefits of informal caregiving such as the financial ben- efit and patient's comfort, it is expected that modern society and insurance companies will encourage the model of informal long-term care as a substitute for institutionalization, especially of the elderly ${ }^{47}$. However, it should be emphasized that according to some authors the substitution of formal care with informal care is recommended primarily for those patients who do not high level of disability and do not require special skills from caregivers to conduct care as otherwise they can lead to overburdening of informal caregivers ${ }^{4}$. The society has to organize support that includes giving information, counseling, psychosocial support, caregiving education and coping skills, as well as financial support to prevent the overburden and negative impacts to the health of care providers ${ }^{48}$. It is also very important to recognize the predictors of high burden such as mental and physical status of the care recipient, the status of the primary caregiver, living with the patient in the same household, female gender, feeling of loneliness, and providing high intensity care ca-52. $^{49}$

Assessment of burden predictors before taking over the role of informal caregivers and recognizing the overburden on time are essential for adequate informal care. Therefore, it is very important to put the focus on the health condition of informal caregivers and find out their problems, needs and possibilities through conversation ${ }^{53}$. If there is a high risk for mental and physical health of informal caregivers, they should be protected and the care recipient should be institutionalized ${ }^{54-56}$.

The first limitation of this study is the relatively small sample recruited only in the capital of Croatia so in the subsequent studies including informal caregivers from other parts of Croatia should be considered. The second limitation is the usage of different types of respiratory support among informal care recipients since it can be assumed that patients using mechanical ventilation are more functionally dependent and require more help than patients with long term oxygen therapy.

\section{Conclusion}

The results of this study show that more than half of informal caregivers of chronic respiratory failure patients are moderately to severely burdened. High level of burden can have a negative impact on the informal caregiver's health and quality of life which is why the informal caregivers can become hidden patients. The burden should be prevented with timely recognition of the burden predictors. If the burden is already present, the negative impacts can be reduced with implementation of specific interventions and organized support for care providers. This information can have an impact on the planning and organizing support for informal caregivers in Croatia. It should also be emphasized that informal caregivers need to be engaged as equal members of medical team caring for the patient. 


\section{R E F E R E N C E S}

1. KEMPER P, Gerontologist, 43 (2003) 436. - 2. NATIONAL INSTITUTE FOR AGEING, Long term-care: What is long-term care? Available from: https://www.nia.nih.gov/health/what-long-term-care. - 3 . COLLINS LG, SWARTZ K, Am Fam Physician 83 (2011) 1309. - 4. BONSANG E, J Health Econ, 28 (2009) 143. doi:10.1016/j.jhealeco.2008.09.002. - 5. REINHARD SC, LEVINE C, SAMIS S, HOME ALONE: Family Caregivers Providing Complex Chronic Care (AARP Public Policy Institute, Washington, 2012). - 6. CARRETERO S, GARCES J, RODENAS F, SANJOSE V, Arch Gerontol Geriatr, 49 (2009) 74. doi: 10.1016/j.archger.2008.05.004. - 7. KHALAILA, R, LITWIN H, J Adv Nurs, 67 (2011) 1614. doi: 10.1111/j.1365-2648.2010.05606.x. - 8. REINHARD SC, GIVEN B, PETLICK NH, BEMIS A, Supporting Family Caregivers in Providing Care. In: HUGHES RG (Ed) Patient Safety and Quality: An Evidence-Based Handbook for Nurses (Agency for Healthcare Research and Quality, USA, 2008). — 9. SCHULZ R, SHERWOOD P, Am J Nurs, 108 (2008) 23. doi: 10.1097/01.NAJ.0000336406.45248.4c. - 10. PEREZ AG, ROSE KM, CACERES BA, SPURLOCK W, BOWERS B, Nurs Outlook, 66 (2018) 337. - 11. GAUGLER JE, KANE R, LANGLOIS J, Assessment of family caregivers of older adults. In: ROBERT K, KANE R (Eds) Assessing older persons - Measures, meaning and practical applications (Oxford University Press, 2000). - 12. HOOPS M, IADELUCA L, MARGARET MCDONALD M, MAKINSON GT, J Multidiscip Healthc, 10 (2017) 437. doi: 10.2147/JMDH.S135372. - 13. DONOVAN ML, CORCORAN MA, Am J Occup Ther, 64 (2010) 590. doi: 10.5014/ajot.2010.09064. - 14. EDWARDS M, Phys Occup Ther Geriatr, 33 (2015) 220. doi: 10.3109/02703181.2015.1031926. - 15. DRUMOND JD, BROTMAN S, SILVERMAN M, SUSSMAN T, ORZECK P, BARYLACK L, WALLACH I, J Wom Soc Wo, 28 (2013) 415. doi: 10.1177/0886109913504154. - 16. HARRIS SM, ADAMS MS, ZUBATSKY M, WHITE M, Aging Ment Health, 15 (2011) 950. doi: 10.1080/13607863.2011.583629. - 17. YOUELL J, CALAGHAN JEM, BUCHANAN K, Ageing Soc, 36 (2015) 946. doi: 10.1017/S0144686X15000045. - 18. HÉBERT R, BRAVO G, PRÉVILLE M, Can J Aging, 19 (2010) 494. — 19. LU L, WANG L, YANG $\mathrm{X}, \mathrm{FENG} Q$, Psychiat Clin Neuros, 63 (2009) 730. doi: 10.1111/j.1440-1819.2009.02019.x. - 20. CHATTAT R, CORTESI V, IZZICUPO F, DEL RE ML, SGARBI C, FABBO A, BERGONZINI E, Int Psychogeriatr, 23 (2011) 797. doi: 10.1017/S1041610210002218. - 21. AL-RAWASHDEH SJ, LENNIE TE, CHUNG ML, J Cardiovasc Nurs, 31 (2016) 21. doi: 10.1097/JCN.0000000000000348. — 22. BEDARD M, WILLIAM MOLLOY W, SQUIRE L, DUBOIS S, LEVER JA, O'DONNELL M, Gerontologist 41 (2001) 652. doi: 10.1093/geront/41.5.652. - 23. HARKNESS K, TRAMNER J, Can J Cardiol, 23 (2007) 322. - 24. MOORE CD, J Fam Soc Work, 13 (2010) 451. doi: 10.1080/10522158.2010.514681. - 25. KNIGHT BG, FOX LS, CHOU CP, Gero Psych, 6 (2000) 249. — 26. - LONGMIRE FCV, KNIGHT BG, Gerontologist, 51 (2011) 453. doi: 10.1093/geront/gnr011. - 27. ANKRI J, ANDRIEU S, BEAUFILS B, GRAND A, HENRARD JC, Int J Geriatr Psychiatry, 20 (2005) 254. doi: 10.1002/gps.1275. - 28. SPRINGATE BA, TREMONT G, Am J Geriatr Psychiatry, 22 (2014) 294. doi: 10.1016/j. jagp.2012.09.006. - 29. WHITLATCH CJ, ZARIT SH, EYE VON A, Gerontologist, 31 (1991) 9.- 30. DARRAGH AR, SOMMERICH CM, LAV-
ENDER SA, TANNER KJ, VOGEL K, CAMPO M, J Appl Gerontol, 34 (2018) 734. doi: 10.1177/0733464813496464. - 31. FEINBERG LF, The state of the art: Caregiver assessment in practice settings. (Family Caregiver Alliance, San Francisco, 2002). - 32. DEL-PINO-CASADO R, CAR DOSA MR, LÓPEZ-MARTÍNEZ C, ORGETA V, PLoS One, 14 (2019) e0217648. doi: 10.1371/journal. — 33. VAN PELT DC, MILLBRANDT EB, QUIN L, WEISSFELD LA, ROTONDI AJ, SCHULZ R, CHELLURI L, ANGUS DC, PINSKY MR, Am J Respir Care Med, 175 (2007) 167. 34. DOUGLAS SL, DALY BJ, Chest, 123 (2003) 1073. doi: 10.1378/ chest.123.4.1073. - 35. SIMPSON C, YOUNG J, DONAHUE M, ROCK ER G, Int J Chron Obstruct Pulmon Dis, 5 (2010) 141. - 36. SPILLMAN BC, LONG SK, Inquiry, 46 (2009) 140. doi: 10.5034/inquiryjrnl_46.02.140. - 37. SAUTTER JM, TULSKY JA, JOHNSON KS, OLSEN MK, BURTON-CHASE AM, LINDQUIST JH, ZIMMERMAN S, STEINHAUSER KE, J Am Geriatr Soc, 62 (2014) 1082. doi: 10.1111/jgs.12841. — 38 DEEKEN JF, TAYLOR KL, MANGAN P, YABROFF R, INGHAM JM, J Pain Manag, 26 (2003) 922. doi: 10.1016/s0885-3924(03)00327-0. — 39. VISSER-MEILY AJM, POST MWM, RIPHAGEN II, LINDERMAN E, Clin Rehabil, 18 (2004) 601. doi: 10.1191/0269215504cr776oa. - 40 SHERWOOD PR, GIVEN CW, GIVEN BA, VON EYE A, J Aging Health, 17 (2005) 125. doi: 10.1177/0898264304274179. — 41. SCHULZ R, SHER WOOD P, Am J Nurs, 108 (2008) 23. - 42. METZELTHIN SF, VERBAKEL E, VEENSTRA MY, VAN EXEL J, ANTONIUS W AMBERGEN AW, KEMPEN GIJM, BMC Geriatrics, 17 (2017) 232. doi: 10.1186/s12877017-0620-3. - 43. VERBAKEL E, TAMLAGSRØNNING S, WINSTONE L, FJÆR EL, EIKEMO TA, Eur J Public Health, 27 (2017) 90. doi 10.1093/eurpub/ckw229. — 44. PODGORELEC S, KLEMPIĆ S, Migracijske i etničke teme, 23 (2007) 111. - 45. NATIONAL ALLIANCE FOR CAREGIVING, Caregiving in US 2015. Available from: https://www.caregiving.org/wpcontent/uploads/2020/06/AARP1316_RPT_CaregivingintheUS_WEB.pdf. - 46. SPILLMAN, BC, LONG SK, Inquiry, 46 (2009) 140. - 47. BAĐUN M, Newsletter, 101 (2015) 1. Available from: https:// bib.irb.hr/datoteka/788580.100.pdf. - 48. DAMIANI G, FARELLI V, ANSELMI A, SICURO L, SOLIPACA A, BURGIO A, BMC Health Serv Res, 11 (2011) 316. - 49. ADELMAN RD, TMANOVA LT, DELGADO D, JAMA, 311 (2014) 1052. doi: 10.1001/jama.2014.304. - 50. NATIONAL ALLIANCE FOR CAREGIVING, Caregiving in US, 2020. Available from: https://www.caregiving.org/caregiving-in-the-us-2020/ - 51. ZHU W, JIANG Y, J Stroke Cerebrovasc Dis, 27 (2018) 3636. doi: 10.1016/j.jstrokecerebrovasdis.2018.08.037. - 52. YEE JL, SCHULZ R, Gerontologist, 40 (2000) 147. doi: 10.1093/geront/40.2.147. - 53. KELLY K, WOLFE N, GIBSON MJ, FEINBERG L, Listening to Family Caregivers: The Need to Include Family Caregiver Assessment in Medicaid Home- and Community-Based Service Waiver Programs (AARP's Public Policy Institute, Washington DC, 2013). - 54. ETTERS L, GOODALL D, HARRISON BE J Am Acad Nurse, 20 (2008) 423. doi: 10.1111/j.1745-7599.2008.00342.x. - 55. CARESS AL, LUKER KA, SALMON MP, 18 (2009) 479. doi: 10.1111/j.1365-2702.2008.02556.x. - 56. NORTHOUSE LL, KATAPODI M, SONG L, ZHANG L, MOOD DW, CA Cancer J Clin, 60 (2010) 317. doi: 10.3322/caac.20081.

\section{S. Benko}

Special Hospital for Lung Disease, Rockefellerova 3, 10000 Zagreb, Croatia

e-mail: snjezanabenko@windowslive.com 


\section{OPTEREĆENOST NEFORMALNIH NJEGOVATELJA OSOBA S KRONIČNIM RESPIRATORNIM ZATAJENJEM U HRVATSKOJ}

\section{S A Ž E T A K}

Cilj ovog rada je odrediti stupanj opterećenosti neformalnih njegovatelja osoba s kroničnim respiratornim zatajenjem mjeren pomoću Zarit Burden Interview upitnika i identificirati one najopterećenije koji i sami mogu postati skriveni pacijenti. Ispitanici su okupljeni u dvije bolnice za plućne bolesti u Zagrebu i Ustanovi za zdravstvenu njegu u kući grada Zagreba tijekom 2020. godine. Nakon što su identificirani kao primarni neformalni njegovatelji koji pružaju intenzivnu neformalnu skrb duže od šest mjeseci, zamoljeni su da popune hrvatsku verziju ZBI upitnika i upitnik o sociodemografskim obilježjima. U ovom presječnom istraživanju u svrhu statističke analize korištene su deskriptivne metode. Rezultati su prikazani tablično kao apsolutne frekevencije, u postocima i mjerama centralne tendencije te grafički pomoću dijagrama. U istraživanju je sudjelovalo 150 neformalnih njegovatelja. Većina ispitanika bile su žene, starije od 50 godina, sa srednjoškolskim obrazovanjem. Najveći postotak neformalnih njegovatelja bio je u mirovini. Najviše ocjene u upitniku zabilježene su u tvrdnjama na temu zabrinutosti za budućnost bolesnog člana obitelji i njegove ovisnosti o neformalnom njegovatelju. Najniže ocjene zabilježene su u tvrdnjama koje se tiču prepuštanja skrbi nekome drugom i osjećaja poput bijesa ili neugode koje je izazvao bolesni član obitelji. Rezultati ovog istraživanja pokazuju kako je više od polovice neformalnih njegovatelja bolesnika s kroničnim respiratornim zatajenjem umjereno do teško opterećeno. 